\title{
ON THE ECHINATE QUESTION OF WHAT MIGHT BE MEANT BY THE TERM 'RESEARCH' WHEN EVALUATING AND DISCUSSING VISUAL ART
}

Mark Baskett

Eighteen months ago, I was asked by two staff members from the Dunedin School of Art to develop a discussion around the role of research in my ongoing artistic practice. This article has been written following the presentation of that discussion - delivered on the Ist April 2021, within the time of my residency at the art school.

For me the term research is at once productive and problematic - a term whose usage today seems quite widespread and ubiquitous in much discourse in the area of visual arts. Interested in exploring ideas around art and research, I first provide some grounding remarks on the emergence of the term in the broader field of fine arts education and art practice. Next, some of the concerns found nesting in these grounding points will be threaded into four examples from my own artwork made over the last 20 years.

Obviously, I am not the first artmaker to have questioned the use of the term 'research' in arts institutions and in much of the discourse surrounding visual art today. Considering this, and when looking into the origins of the more recent use of the term, it is informative to bear in mind the rather matter-of-fact remark by the Chicago-based academic James Elkins: "the initial impetus behind the terms research and new knowledge is purely economic."' As Elkins goes on to note, it was during the 1980s, in the United Kingdom, Ireland and Australasia, that changing models for funding arts programmes made the inclusion of more lucrative higher degrees an attractive - even an essential - part of a school's offering for potential students. ${ }^{2}$

Beyond these financial concerns tied directly to academia and shifting models of state funding for arts institutions, other forces emerged in the 1980s that would further emphasise the idea that wider economic benefits could be gained through research-focussed, university-level arts education. Judith Mottram made these economically motivated ideas quite clear when she wrote in a in 2009 article:

The mid-late 1980s saw design hailed as the possible saviour for UK manufacturing and trade. Interest in how design adds value to commodities contributed to the modelling of 'the creative industries.' Building upon the theorisation of design research at the Royal College of Art in the 1970s (Archer 1979), doctoral activity began to emerge across all art and design disciplines, encouraged by the Council for National Academic Awards (CNAA). ${ }^{3}$

Mottram directly experienced the force of these ideas when she began her doctoral pathway in 1984. Funding for her fine arts-focussed PhD was justified by her principle supervisor, who argued that fine art's ability to influence design would help to inspire future designers as they worked to support the economic goals of these newly named "creative industries."

Two decades on from this shift in the United Kingdom (if I can stay with the example of the UK for a moment), Professor Sir Christopher Frayling - then rector of the Royal College of Art in London - took time to reflect on the progress and presence of research in visual arts education. In his foreword to the 2006 book Thinking Through Art: Reflections on Art as Research, Frayling asserted that confusion exists around how academic research 
might be applied to the area of fine arts. ${ }^{5}$ Perhaps most urgent among the concerns expressed by Frayling is the selection of an appropriate methodological framework when making art that lays claims to being art-as-research. How might the tradition-based quantitative, qualitative or mixed-methods approaches be employed within the context of an art project? Added to this, questions remained for Frayling about the art project's ability to produce clearly communicable results that can be seen to produce new knowledge and understanding. The application of established research practices to the field of visual art might well help the viewer of an artwork to locate characteristics such as technical proficiency, the display of competency, or even a type of 'correctness' in approach - but does this, Frayling asks, help support and promote creative artistic output? ${ }^{6}$

Frayling was certainly not alone in having these concerns, for a year after making these remarks the Arts and Humanities Research Council of England conducted a review of practice-led research in art, design and architecture, noting that: "In particular we have come to the conclusion that conventional ideas of contribution to knowledge or understanding may not be serving us well. This is significant to fine artists but we believe that it is relevant across ADA [the fields of Arts, Design, and Architecture] and a shared effort to develop appropriate new models would be a constructive development."7

With these initial remarks in mind, l'd like to offer some examples from my own work as a maker of visual art. My interest here is in considering an individual working within this time of flux and change, where ideas around research are slowly entering into both the teaching and the making of visual art. My first example concerns an individual working at a small institute then titled the Quay School of the Arts. Tucked away in Whanganui, New Zealand, it was an educational facility based in the centre of a small city of around 60,000 residents, a city known for its high number of retirees and its relatively large Māori population. When I was attending, the school boasted a roll of around I 30 students, all enrolled to do a BFA degree; unusually, most of the faculty were lecturers from the US, whose teaching provided a distinctly North American slant to course content and the degree's overall perspective.

Like many others entering tertiary arts education, I found that this course offered my first sustained and concentrated look into the question of what it might mean to produce contemporary visual art. Unlike BFA programmes offered in New Zealand today, the Quay School course spanned not three, but four years of full-time tuition. With this added time component, and following the legacy of the Bauhaus, the first year of study sent students through all the school's departments to undertake five-week block courses, focussed squarely on an engagement with the functional properties of materials - be they glass, clay, paint, plaster or print film, or the scratched lines in a copper etching plate.

To complete the final year of this intensive time of study, I submitted an installation around the size of a double garage - a work that can be seen in Figure I. Housed within this artwork were a number of kinetic objects: a swivelling hairdryer tightly cloaked in bright green vinyl; a pendulous sculptural work powered by an old clock mechanism; and a smaller work vaguely resembling a piece of gym equipment that, when operating, powered a wheezing rubber bellows.

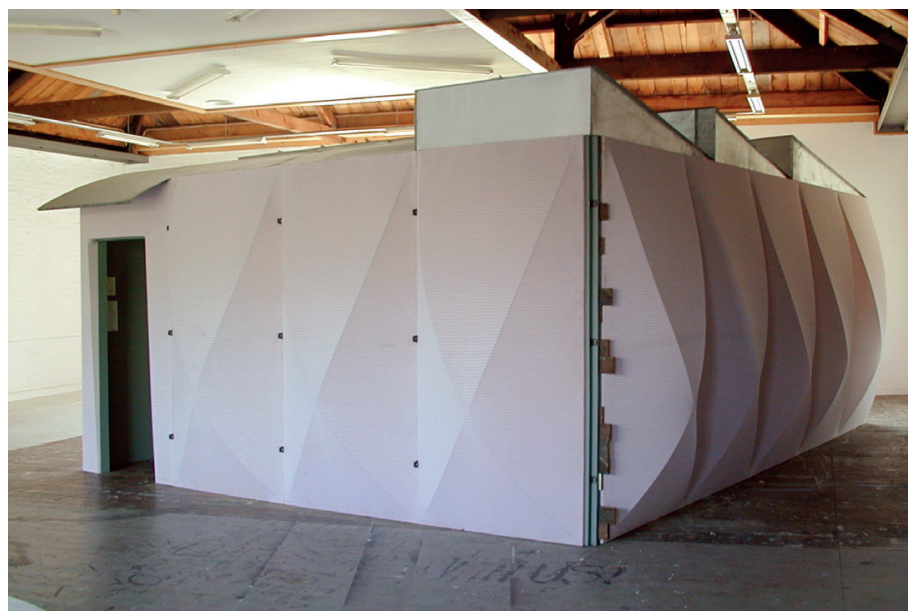

Figure I. Mark Baskett, Big Pink, 200 I, mixed media installation, $5.2 \times 6.8 \times 2.8$ m. Whanganui, New Zealand. 
At the centre of this installation stood a tall, painted sheet-steel object that encased "The Electro-Blitz 2000" - a recycled and repurposed fly zapper (Figure 2.). Five cast glass discs slowly rotated around this object, and each disc supported a tiny diorama made up of model vehicles and tiny plastic characters posing motionless beside small piles of multicoloured, rotting foodstuffs. Occasionally the quietness of this slowly moving work would be interrupted by a zzziitt and the fatal last light of an insect attracted to the artwork's rotten food.

Regarding the question of research and what research might have been conducted in relation to the artwork briefly described here, a number of things can be said to have occurred. Yes - the artwork was produced while investigating various artist models, learning about art history, and delving into a small selection of concepts, theories and socio-cultural ideas. When I was involved in these activities, the US perspective was certainly felt - at times perhaps, even at the expense of paying closer attention to the New Zealand context existing in and just outside the classroom door. In the sculpture department within which I was nestled, figures like Robert Gober, Ed Kienholz, David Lynch and Martin Puryer were prized and often referenced and discussed. A strong emphasis was also placed on a form of visual art that favours

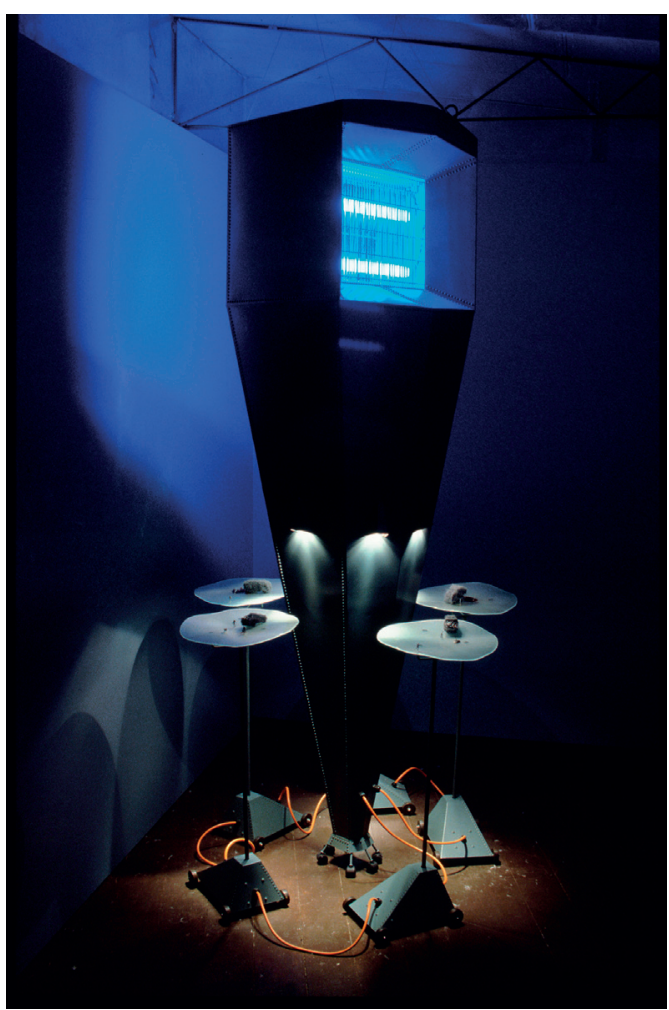

Figure 2. Mark Baskett, Big Pink, 200 I, mixed media installation, $5.2 \times 6.8 \times 2.8 \mathrm{~m}$. Whanganui, New Zealand. imaginative exposition and the exploration of certain internal states of mind. Yet if you wanted to delve more deeply into concepts and ideas - such as spatial practice as articulated by Henri Lefebvre, or theoretical reflections on the work of Len Lye, or the work of bell hooks or Judith Butler - then you were left much more readily on your own.

Looking back now, it seems reasonable to assert that specific notions and assumptions about the make-up, presence and place of creativity were present within the Whanganui-based BFA programme, and that these notions and assumptions share parallels with many other arts institutions. Mottram outlines these potential assumptions when surveying notions of creativity present in UK arts institutions, questioning how specific ideas about creativity might affect the practice research relating to art: "Some of the confusion about research and art practice stems from the high value accorded to creative drives and outputs, and the perception that they are also inexplicable. Livingston noted how the notion 'analysis leads to paralysis' was commonplace (Livingston 1989: I 3), and Boden described this as a mistaken belief that creativity should not be 'sullied by the tentacles of scientific explanation' (Boden 1990:14)."'8

Four years on from completing a BFA qualification, I entered an MFA programme titled "Kunst im Öffentlichem Raum: Public Art and New Artistic Strategies," run through the Bauhaus-Universität in Weimar, Germany. This graduate programme was divided into four separate assessments, where within each semester it was expected that students successfully complete seminar work and produce a distinctive work or works for submission and evaluation. Additionally, it was required that in the fourth and final semester the production of an artwork would be accompanied by an MFA thesis. 
The first semester began with the development of work for public exhibition in the city of Leuven - a small, affluent town located in the heart of Flemish-speaking Belgium. MFA students from the Bauhaus Universität were teamed up with students from the University of Sint Lukas, Brussels, and were asked to respond to a very particular thematic - the relationship between the prison and transit camp of Breendonk in Nazi-occupied Belgium and the concentration camp of Buchenwald in Weimar, Germany, during the Second World War. For many involved in this public exhibition - some of whom were new to both Belgium, Germany and indeed the continent of Europe - the sheer weight and complexity of the exhibition's subject appeared quite unfathomable; whether spoken of or not, discussions that took place during the exhibit's preparation seemed to be made under the shadow of an unexperienced and ultimately unimaginable background of violence and catastrophe. As a result, the public artworks that came out of this process varied greatly in their preparedness or even interest to address the given theme.

In an effort to somehow limit the vastness and complexity of this subject, I tried to confine myself to contemporary Belgian society, focusing on the iconography of nationalism, the Belgian political party known as the Vlaams Belang,' and the increasing popular interest in Belgium in far-right political ideologies. The artwork that developed (see Figure 3) looked toward monuments: both as a distinct artistic genre and as a visual means through which political and ideological views can be captured, given form, and expressed.

Making this artwork involved time spent visiting a variety of sites relevant to the subject and the exhibition, where photos, notes and preparatory drawings were made. As with my undergraduate curriculum, artist models were found that relate to the work's subject matter and theme. Time was also spent looking more specifically into artistic strategies and visual language relating to the presentation of right-wing political ideologies. Artists affiliated with the Third Reich, such as Arno Breker, Heinrich Berann and Sepp Hilz, were investigated in the development of this work. I examined Hilz (Figures 4 and 5) for the way in which his work captured an obsessive sense of physical health, moral uprightness and the replacement of any image of political activity with, as Slavoj Žižek puts it," "a single ecstatic vision of a totalitarian family." "| The obscene excess found in works by Arno Breker (see Figure 6) were also of interest, where Breker sought to return visual iconography to a nationally based, imaginary and, above all, heroic warrior past.

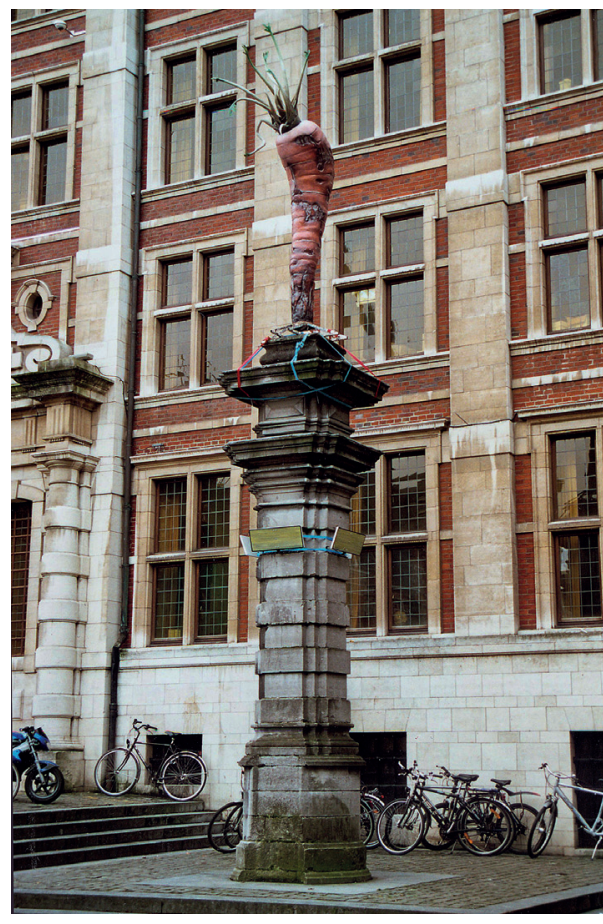

Figure 3. Mark Baskett, Tijdelijk monument voor de nieuwe opkommst van rechts in Belgie, ${ }^{10} 2006$,

temporary public artwork, fibreglass, steel, wood and tie-down ratchet straps. Leuven, Belgium.

This artwork signalled a shift with regard to potential research and my engagement with the problem of making art, where, as Rae Earnshaw noted in his 2016 book, Research and Development in Art, Design and Creativity, "[t]he search for, and impact on, new knowledge currently places responsibilities on the artist-researcher, challenging them to theorise their practice to self, others and communities." 14 Working through the challenges of this art-making framework, it also became quite clear, as Earnshaw remarks, that "it is less and less tenable for artists working in academe to hide behind the role of the mute artist."'15 More generally, at the Bauhaus and during an exchange semester spent at a programme titled "Art in Context," run through the UdK (Universität der Künste Berlin), it was remarkable to observe how many students reacted to the challenges put forward within the MFA programme. The term 'research' was itself becoming more and more widely used, with students presenting themselves as "artist/researchers," "artist/activists," or the tripartite "artist/activist/researchers." 
Figures 4 \& 5. Sepp Hilz, Die Mägde, die Knechte, from his Bäuerliche Trilogie,12 1941, oil on canvas. bpk | Bayerische Staatsbibliothek | Archiv Heinrich Hoffmann.

http://www.hausderdeutschenkunst.de/kuenstler/sepp-hilz/galerie/galerie03.html

Graduating with an MFA in 2007, I was fortunate over the next four years to undertake a variety of artistic projects, including two 12-month residencies in the region of Zurich, Switzerland, and a shorter but highly engaging residency in a programme titled "Pilotprojekt Gropiusstadt" in Gropiusstadt, Berlin. During this time I continued to investigate and produce artwork for temporary display in public space - a strategy that brought a deepening involvement in site-specific, siteinvestigative creative work. This resulted in art projects that sought to locate real-existing social phenomena and tie what was found - be it an object, a story or an event - to the present-day context within which the artwork would be shown.

An example of this approach comes from a residency undertaken in the small city of Uster in 2009- I 0.Though free to develop any type of work during the residency, I applied for this programme declaring my interest in making site-specific art and, when accepted, I quickly

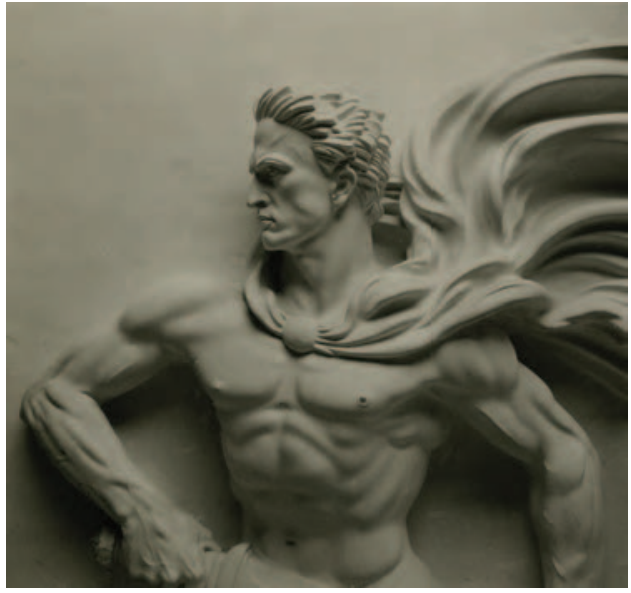

Figure 6. Arno Breker, Der Wächter, from his Die Große Deutsche Kunstausstellung, 13 1942. Munich. bpk | Deutsches Historisches Museum / Ernst Schlumberger, (C) Arno Breker.VG Bild-Kunst/Copyright Agency, 2021. began to familiarise myself with both the history and the current makeup of the city. It did not take long to discover that by the early nineteenth century Uster was not only the most heavily industrialised area of Switzerland, but also in broader continental Europe. The river that runs through Uster was, for a time at least, the driving force behind this originally water-powered industrial development. By the 1970s, however, all but one of the city's many cotton spinning factories had closed, leaving Uster to come to terms with its new post-industrial era. 
Over the last few decades, many attempts have been made in Uster to revitalise this once heavily industrialised space; in particular, I was struck by the so-named "cultural pathway" developed by the Swiss architect, Hans Baatschi. Titled "Industriepfad Uster," his project involved placards placed along the riverway that courses through Uster, each placard and its associated information panel referring to a specific factory site and adjoining private land. It was an attempt (the first made in Switzerland) to musealise the former industrial sites of a town.

Other attempts to stimulate Uster's economy have included a private/public partnership between the last surviving textile business, Zellweger AG, and the city's technical training institute, the Berufsschule Uster. Here a new focus was placed on vocational training for making high-end products and high-tech textile production. Interested in these activities, I went to visit Herr Steinlin, a long-time teacher at Uster's technical training institute. With a wry smile he led me into the basement of the school to show me a rather neglected and out-of-the-way display cabinet. In it sat a Dutchmade Philips P2000T - a 1982 Z80-based computer with a memory capacity of up to 48KB. Following its purchase by the Berufsschule Uster, in partnership with Zellweger AG, for an alleged purchase price of 15,000 Swiss francs, it was hoped that with proper training a new era in Swiss-led innovation and industry would now be launched and set into motion.

In the months leading up to the exhibition of this art project, the catchment pond attached to Zellweger AG was drained and extensively cleaned. Following the shift from water to electrical power, it had reportedly become standard practice for the company to dump disused machinery into the murk of its privately

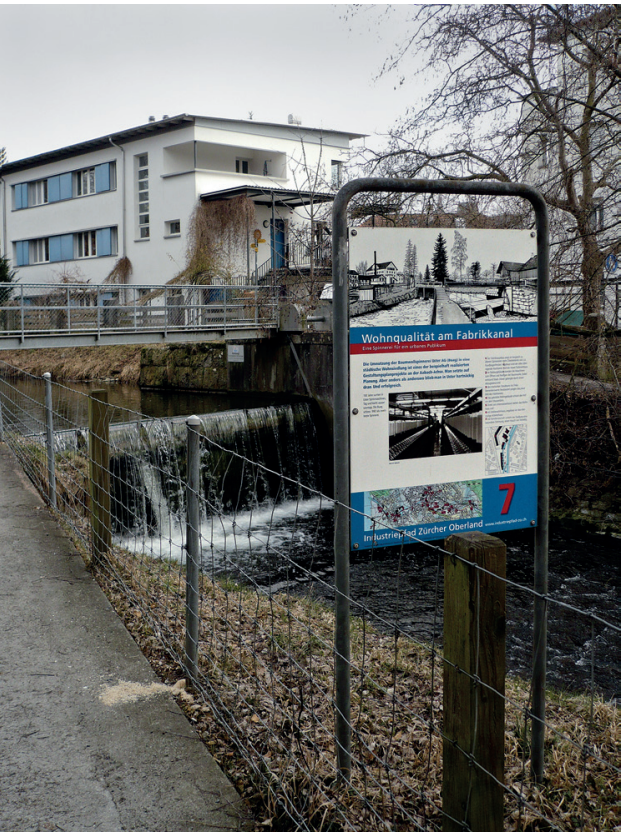

Figure 7. Hans Baatshi, Industrie Pfad Uster, Station 7.

Uster, Zürich. Author's photograph, 2010. owned pond. At an estimated cost of over two million Swiss francs, a clean-up was now underway - a prerequisite for the sale of the pond and its surrounding land back to the city council of Uster.

Utilising the pre-existing display platform developed by the Industriepfad of Uster, the artwork (see Figure 8) went on display. It can be seen here at a depth of about half a metre under the surface of the pond, with Figure 9 showing a detail of the work.

My approach to artmaking changed direction again in late spring of $201 \mathrm{I}$ with the unexpected announcement of impending fatherhood. Residencies and the time investment dedicated to making public art suddenly seemed unsustainable; I noticed, too, that when undertaking site-specific public art projects, the documentation of the work and creating a narrative around its themes was occupying more of my time and creative interest. With these considerations in mind, and with many other factors besides, I began to seriously reconfigure my approach to making visual art.

Some of the results of this reconfiguration can be seen in my exhibition, "The Neighbourhood - Selected Works 2017-202I," shown during the period in which I undertook the Dunedin School of Art residency (see Figure 10). Blocks of text are presented along with imagery - yet rather than using the written word as I had done earlier, these new works marked a different approach to the use of text. Following a suggestion put forward by the acclaimed feminist theorist and scholar Peggy Phelan, language has been used here as a way to write with rather than about its 


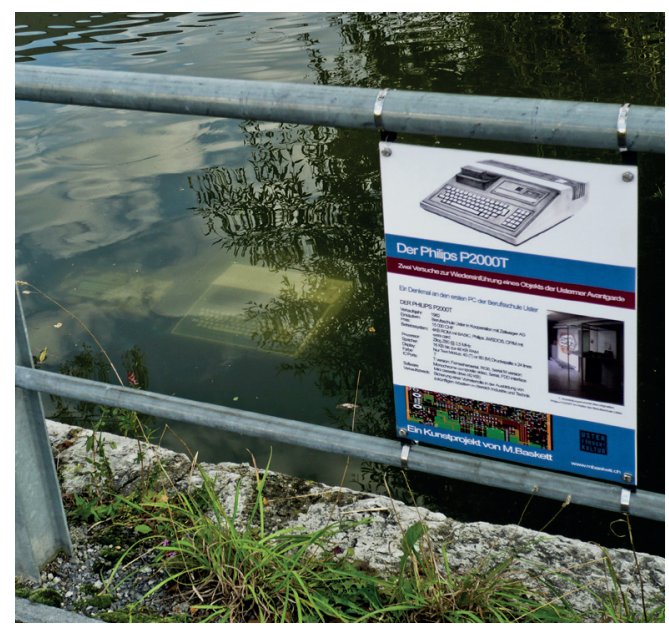

Figutre 8. Mark Baskett, DER PHILIPS P2000T: Zwei Versuche zurWiedereinführung eines Objekts der Ustermer Avantgarde, ${ }^{16}$ 2010, temporary public artwork. Uster, Switzerland.

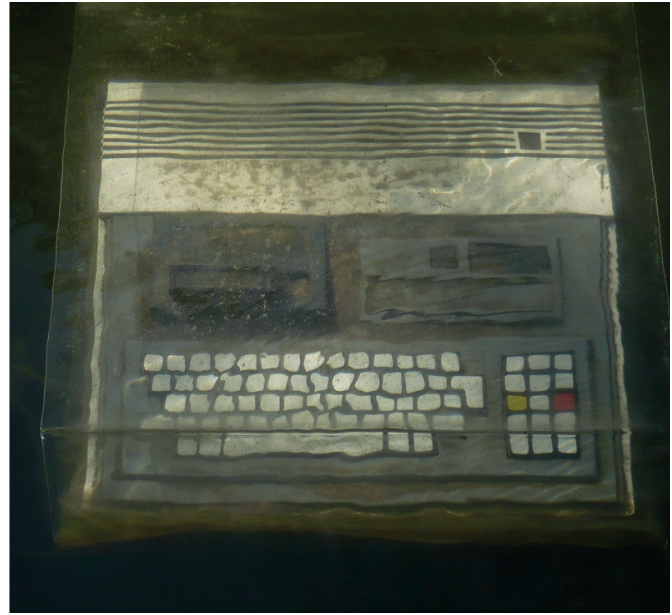

Figure 9. Mark Baskett, DER PHILIPS P2000T: Zwei Versuche zur Wiedereinführung eines Objekts der Ustermer Avantgarde, 2010, temporary public artwork (detail). Uster, Switzerland.

subject and, in this sense, words try to "gallop up" alongside a work. ${ }^{17}$ Not to master, dominate or explain an image, but to seek instead to provide a sense of specificity, and create, if possible, a level of narrative intimacy as the text drives the viewer back towards the image.

And whether the subject matter is (as in Figure 10) a suburban name such as Maryhill; whether the focus lies on the radically different conceptions of land use and land ownership between Māori and Pākehā; or whether the theme is the influence of coal in shaping the cityscape of twentieth-century Dunedin: all these elements seek to put an imaginative pressure on the recognisable, and then ask how they might shape a vision of a place today.

So to conclude, for the moment, I would like to suggest that, on the one hand, research is for me quite a productive term, for I like the way it seems to imply a 'careful search.'The term also seems productive for the way it implies a constant questioning of one's work in terms of its materiality and form - asking what art can physically be, how it might arise, and what it might (or might not) in some way seek to do. Like others, I too am interested in the idea that when investigating your topic, you develop what can be called a logic internal to the work. Henk Slager points to this in his article in the book Artists with PhDs: "Artistic research can never be characterized by a well-defined, rigid methodology $[\ldots]$ it entails a strong belief in a methodological articulable result founded by operational strategies that cannot be legitimized beforehand. Indeed, that is the essential characteristic of artistic research."18

I am also, nonetheless, left with a number of questions and uncertainties, particularly with regard to artistic research and the production of new knowledge and clearly articulable forms of understanding. These questions and uncertainties echo the concerns of Sir Christopher Frayling outlined at the beginning of this article. Frayling's concerns seem to centre on what might or might not be occurring when we encounter and experience a work of visual art. Do our encounters, for example, rely not on clearly articulable forms of understanding, but rather, on a shift away from any form of stable signification into an immersion in the work's internal process? Is Adorno correct when claiming that the aesthetic experience of an artwork is in fact characterised by an interminable sense of processuality? ${ }^{19}$ And if so, does it follow that an artwork defines itself by its ability to negate any rise to the level of clearly articulable understanding? And what might be the consequences if we accept the idea that the artwork only exists so long as it holds the viewer in state of undecidability, where not knowledge, but a relation of "configurative discontinuity" 20 gives the work its momentum and its drive? 


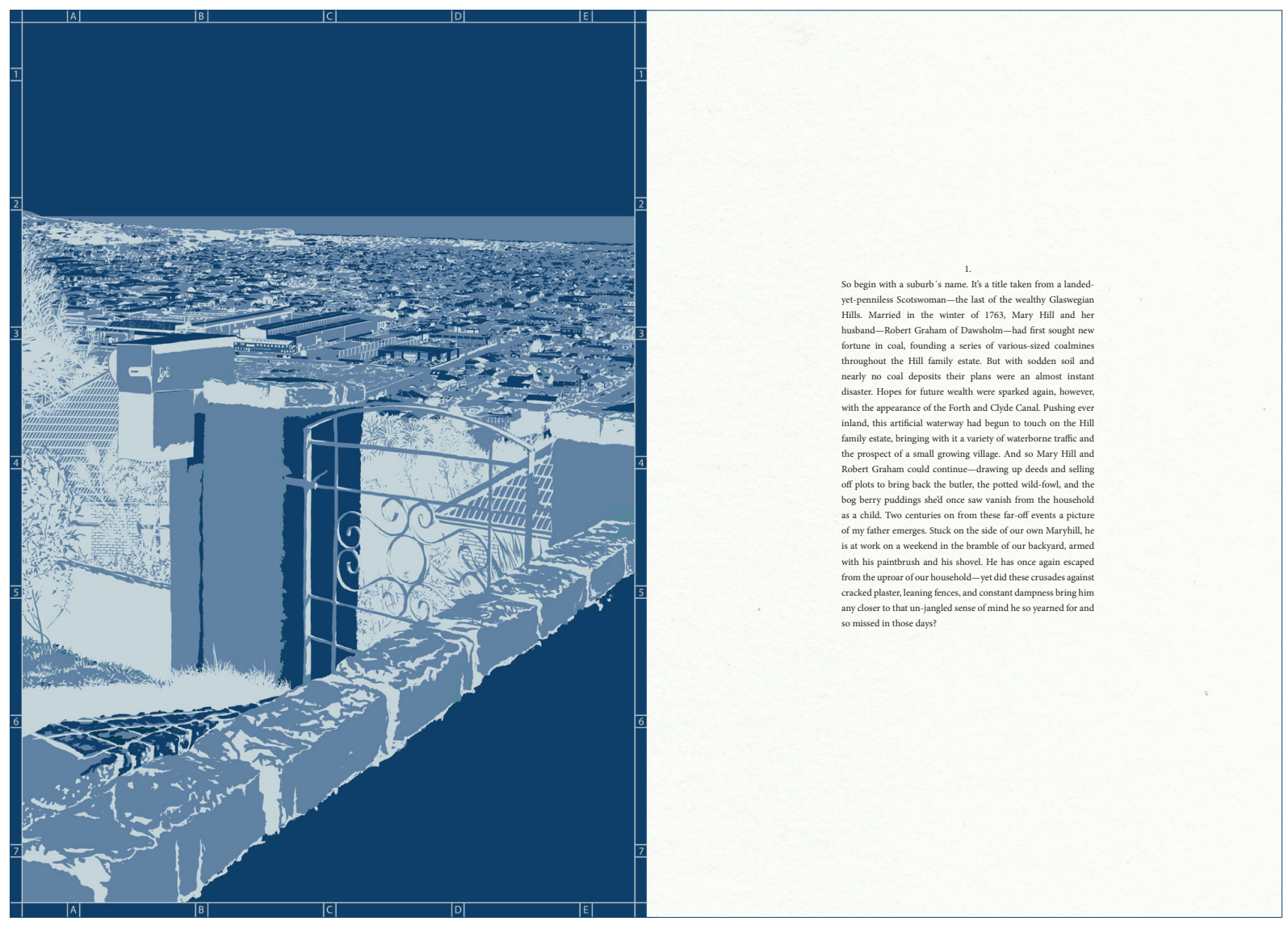

Figure 10. Mark Baskett, The Neighbourhood, 2017-21, inkjet print, $450 \times 620 \mathrm{~mm}$ (exhibition detail).

Reflecting on these questions, and thinking about research and art, I now suspect that over the last 20 years I have extended my involvement into what I would call 'background research' in order to help deepen my engagement with what I'm doing. The role of research here - if indeed the term 'research' really fits at all - follows Mottram when she discusses a form of artmaking that involves the accumulation of diverse and various materials for the purpose of driving forward ongoing creativity.21 As to epistemic questions of new knowledge or clearly articulatable understanding - at present, I still wonder whether these terms really apply when thinking through visual art. But perhaps this can be left for the viewer to decide. 
Mark Baskett is a practicing visual artist, born in Dunedin, New Zealand. He holds a BFA from what was then The Quay School of Arts, in Whanganui, New Zealand, and an MFA from the Bauhaus Universität, in Weimar, Germany. To date his work has been shown in Switzerland, Germany, Belgium, the United States, and New Zealand. In addition to artmaking, he is currently employed part time as a teacher in the Arts and Media Department at the Nelson Polytechnic (NMIT).

I James Elkins, "Afterword," in Thinking Through Art: Reflections on Art as Research, eds Katy MacLeod and Lin Holdridge (London: Routledge, 2006), 241.

2 Ibid.

3 Judith Mottram, "Asking Questions of Art: Higher Education, Research and Creative Practice," in Practice-led Research, Research-led Practice in the Creative Arts, eds Hazel Smith and Roger T Dean (Edinburgh: Edinburgh University Press, 2009), $229-51$, at 233.

4 Ibid, 234 .

5 Christopher Frayling, "Foreword," in MacLeod and Holdridge, Thinking Through Art, xii-xiv, at xiii.

6 Ibid, xiv.

7 Chris Rust, Judith Mottram and Jeremy Till, AHRC Research Review, Practice-led Research in Art, Design and Architecture, http:// shura.shu.ac.uk/7596/I/Pactice-ledReviewNov07.pdf, 23.

8 Mottram, "Asking Questions," 230.

9 "The Flemish Interests Party."

10 "Temporary monument to the new rise of the right in Belgium."

I I S Žižek, M Aristodemou, S Frosh, et al., "Unbehagen and the Subject: An Interview with Slavoj Žižek," Psychoanalysis, Culture and Society, 15 (2010), 4I 8-428, https://doi.org/10.1057/pcs.2010.22.

12 Sepp Hilz, "The maidservants, the farmhands," from his "The Rural Trilogy." (C) bpk / Deutsches Historisches Museum / ErnstSchlumberger

13 Arno Breker, "The Guardian," from his "The Great German Art Exhibition."

(c) Arno Breker.VG Bild-Kunst/Copyright Agency, 2021.

I4 Rae Earnshaw, Research and Development in Art, Design and Creativity (London: Springer, 20 I6), 24.

15 Ibid.

16 "THE PHILIPS P2000T:Two attempts at the reintroduction of an object from Uster's avant-garde."

17 Peggy Phelan and Helena Reckitt, Art and Feminism (London: Phaidon Press, 200 I), 38.

18 Henk Slager, "Art and Method," in Artists with PhDs: On the New Doctoral Degree in Studio Art, ed. James Elkins

(Washington,

DC: New Academia Publishing, 2009), 55.

19 Christoph Menke, The Sovereignty of Art:Aesthetic Negativity in Adorno and Derrida, trans. Neil Solomon (Cambridge, MA:The MIT Press, 1999), 49.

20 Ibid., 127. 